\author{
N.B. Mikhailova ${ }^{1}$, M.T. Baimukhanova ${ }^{2}$, B.K. Pazylbek ${ }^{2}$ \\ ${ }^{1}$ Director of the international Center for scientific information and education, Dusseldorf, Germany; \\ ${ }^{2}$ Ye.A. Buketov Karaganda State University, Kazakhstan \\ (E-mail:marber_96@mail.ru)
}

\title{
Features of the updated curricula and improvement of the educational process
}

\begin{abstract}
The article discusses the features of the updated education system of the Republic of Kazakhstan. The authors drew attention to the fact that the updated educational program introduced in the sphere of education of the Republic of Kazakhstan is a new program that meets the needs of future generations, meets modern requirements. The article deals with the issue of the teacher's development of innovative technologies in modern conditions of education and the objective necessity of their application in teaching children in their lessons. The relevance of innovative learning according to the authors ' research is the use of personalityoriented learning, as well as the creation of conditions for the disclosure of the creative potential of students. The main goal of education in the modern world - prepare professional, competitive, competent, knows his job in the labour market-oriented direction, able to work effectively at the level of world standards, to grow professionally, to respond effectively to the socio-political processes, adapt quickly to change, able to solve industrial-innovative situation, to Express themselves in accordance with their needs and the needs of society, to freely Express their thoughts, to have a high knowledge of the national language, history, to form domestic and world culture. The article describes that the evaluation system undergoes radical changes and moves to the system of criterion evaluation.
\end{abstract}

Keywords: updated education system, criteria-based assessment, innovative education, information technologies.

«Every citizen of Kazakhstan should understand that education is the most fundamental factor of future success». In an era of youth priority, education should come first. The head of state in his Address N.A. Nazarbayev «new opportunities for development in the conditions of the Fourth industrial revolution», «...if education in the system of values becomes the main value, the nation will be successful», he said [1].

Maximum success in the modernization of the education system of Kazakhstan can be achieved only if all the program settings set in the educational policy will be able to gather the maximum possible potential from the positive potential accumulated by world experience. Therefore, for many countries, especially Central Asia, the issue of modernization of the education system is still relevant.

Today, all countries work with a system of higher quality education. After all, in the modern world, the competitiveness of the country is determined by the intelligence of its citizens, so the education system must develop in accordance with the requirements of the future. In this regard, there was a need to teach students modern methods and ways to educate broad-minded, conscious, free citizens. In addition, we are pleased that this process is actively developing the education system and introducing it into secondary schools.

The updated educational program included in the sphere of education of the Republic of Kazakhstan is a new program that meets the needs of future generations, meets modern requirements. The strategic program of Kazakhstan 2030 is characterized by the formation of a national model of education and linking the education system of Kazakhstan with the world educational space [2]. Currently, Kazakh is the state language, the language of communication is Russian and English is the requirement of the time.

During the years of independence, the country has achieved certain results, along with two processes political reform and economic modernization, now it has begun a new historical stage — the stage of spiritual modernization. Spiritual modernization requires from us the formation of national consciousness, competitive, pragmatic approach to any issues, the preservation of national identity as a whole. The main condition of spiritual modernization is «the desire to be educated, open, prosperous», as the President of Kazakhstan noted in the program article «Look to the future: modernization of public consciousness»....each of us should deeply understand that the main factor of success is education... Here we are talking about the future of our country. His future is in the hands of the younger generation [3]. The current young generation, the future specialist in the tasks set out in article 8 of the Law of the Republic of Kazakhstan «on education»: «it is necessary to master national and universal values, to gain knowledge based on the achievements of science and practice» [4]. Thus, our teachers can make a significant contribution to the development of our 
society only through the introduction of new learning technologies, Informatization of education, competent, high-quality implementation of training with access to international global communication networks, the formation of professional competencies of specialists. These are the teachers of our country who carry out all these things. Accordingly, the requirements for today's teaching community will be increased. They should be diversified, recognizable in the world of news, having personal views, constantly creative searches, improving professional skills, able to defend it, having research abilities, knowledge, reading a lot, skillfully applying knowledge in everyday activities, able to teach their student independently. It is a requirement of life. The teacher must have organizational, constructive, inclined, analytical abilities.

In society, a citizen does not have enough knowledge, and most importantly-the ability to effectively use the knowledge in everyday life. Therefore, special attention is now paid to improving the functional literacy of students. The countries of the Organization for economic cooperation and development (OECD) began to move to a renewed education process 28 years ago. In 1997, many countries agreed to move to a common standard for assessing updated content called PISA. A number of schools in the country took part in determining the quality of education according to this standard in 2009, 2012 and 2015. As a result of this study, the need to improve the functional literacy of students was identified. The reason for updating the content of education. Since the new academic year, this system, that is, the world experience will be implemented in the first grades of all schools in the country.

The importance of updated education is critical thinking, research, experience, use of ICT, communicative communication, ability to work in a team, individually, in pairs, the ability to apply functional literacy, creativity and effective teaching methods necessary for its effective implementation. The feature of the updated educational program is its spiral principle. The curriculum, created on the principle of helicity, is based on the cognitive theory provided in the work of Jerome Bruner «educational process» (1960). Having studied the objectives of training, we were convinced in the preparation of tasks, lessons [5].

In modern conditions of education, the objective necessity is the development of innovative technologies by the teacher and their application in teaching children in their lessons. «How to make a lesson interesting, bright?», «questions should not be troublesome teachers. Interested in, as with discipline their children? How to create the conditions for success for each student in the classroom?».

And this is no accident. A new organization of society, a new approach to life makes new demands on the school. To date, the main purpose of training is not only the acquisition of certain knowledge, skills and abilities by students, but also the preparation of students as an independent subject of educational activity. The basis of modern education is the activity of students, oriented teacher. This goal is the education of a creative, active personality capable of self-improvement and submission to the main tasks of modern education [6].

The relevance of innovative learning is the use of personality-oriented learning, as well as creating conditions for the disclosure of the creative potential of students.

The main objectives of innovative learning::

- students of intellectual, communicative, linguistic and creative abilities of students;

- formation of personal qualities of students;

- the creation of skills that affect educational and cognitive activity, and the transition to a productive creative level;

- formation of key competencies of students.

With these goals the tasks of innovative training are defined:

- optimization of the educational process;

- creating conditions for cooperation between student and teacher;

- development of long-term positive motivation for learning;

- careful selection of material and methods of its transmission.

Innovative learning is based on the following technologies:

- developing training;

- problem-based learning;

- development of critical thinking;

- technology «project» method;

- differentiated approach to learning; 
- creating conditions for success in the lesson;

- information technologies[7].

At the same time, without proper reform of the modern system of training highly qualified personnel, it is impossible to achieve visible results in innovative development. From the point of view of practical criticism, this means that the Higher school should increase active work on the formation of innovationoriented educational and scientific activities. From this point of view, it is necessary to take further steps to reform the higher education system itself with the introduction of the principles of operational adaptation, universal access, material and technical equipment of the educational and research process, maximum personalization of the educational process. The content, technologies of training and retraining of personnel for innovative activities, the innovative component of educational programs, including the adjustment of existing educational standards and quality criteria of the process of engineering and technical training should undergo radical changes.

It should be noted that in its best models, innovative education is aimed not only at outdated education, but also at mastering the basic competence that allows, as necessary, self - education. Such education should therefore be closely linked to traditional practices.

Using these technologies in the classroom has a great advantage. The educational process becomes interesting for students, which increases the activity of students, develops self-education skills in the process of interaction and search. The quality and strength of the acquired knowledge increases. Research skills and abilities are developed, analytical abilities of students are formed. Along with the learning process is the development of communicative qualities and the formation of leadership qualities of the individual.

Especially promising is the "project method», which allows to effectively develop critical thinking, activate the creative activity of the audience, effectively develop the media competence of students [4].

The development of cognitive activity is promoted by non-traditional lessons, which increase the interest of students in the subject and learning in General.

There are many types of non-traditional classes: seminar-lesson, lecture-lesson, conversation-lesson, workshop-lesson, lesson-excursion, lesson-study, lesson-game, KVN-lesson, project protection-lesson, debate-lesson, lesson-conference, theatrical performance-lesson, lesson-masquerade, lesson-journey, lessontest.

Almost all of them allow to ask problematic questions and create problematic conditions, to solve problems of differentiated learning, to intensify educational activities, to increase cognitive interest, to develop critical thinking [6].

The evaluation system is also subject to radical changes and moves to the system of criteria evaluation. In criteria-based assessment, student performance is measured by a specific set of pre-established criteria. Student performance is assessed in two ways: formative assessment and summative assessment. Stimulates the child to a comprehensive search. The advantage of this evaluation system is that the child tends to develop thinking and engage in science. The five-point rating system from the Soviet era was eliminated. Formative assessment is an integral part of the day-to-day learning and learning process and is conducted systematically throughout the quarter. Formative assessment provides feedback between students and the teacher and makes it possible to adjust the learning process without scores or grades. The total assessment is carried out by putting points and grades in order to obtain information about the progress of the student who has completed the sections of the curriculum (General topics and specific) of the training stage (quarter, academic year, level of secondary education). Formative assessment and summary assessment are used in all subjects. In the integrated educational program, as in the field of education, there are other issues related to the teaching of the Kazakh language. The program is aimed at improving the four-language skills of students: listening, speaking, reading, writing. These four skills are placed in the curriculum «spiral method» and are closely related to each other. For example, from simple to complex develop in a spiral and develop only in the oral language, improve the skills of composing complex texts, improve language competence [8].

Around the world, the question of what education systems provide to future generations is being reconsidered. As part of this problem, «what needs to be taught for children to be successful in the twentyFIRST century? what are the effective methods of teaching «and» there are such basic questions as: These questions are closely related to the curriculum and pedagogical techniques used in the implementation of educational programs.

All developed countries have a unique system of higher education of high quality. For the main school, it is necessary to improve the standards of education in all schools to the level of Nazarbayev Intellectual schools. Graduates of the Higher school should be fluent in Kazakh, Russian and English. The result of 
training should master the skills of critical thinking, independent research and deep analysis of information. Basically, the updated education system is a program focused on competence and quality. The importance of updated education is critical thinking, research, experience, use of ICT, communicative communication, ability to work in a team, individually, in pairs, apply functional literacy, creativity and use effective teaching methods (collaborative reading, modeling, evaluation system, effective evaluation strategies) necessary for effective implementation.

The feature of the updated educational program is its spiral principle. The evaluation system is also subject to radical changes and moves to the system of criteria evaluation. In criteria-based assessment, student performance is measured by a specific set of pre-established criteria. Students ' academic performance in a subject is assessed in two ways: a section summary grade (QE) and a quarter summary grade $(\mathrm{QE})$.

Stimulates the child to a comprehensive search. The system of criteria evaluation is used in such developed countries as the Philippines, Singapore, Japan, France, Finland. The advantage of this evaluation system is that the child develops thinking abilities and seeks to engage in science. Formative assessment is an integral part of the day-to-day learning and learning process and is conducted systematically throughout the quarter. Formative assessment provides feedback between students and the teacher, regularly conducting assessment and allows you to adjust the learning process without scores or grades. The total assessment is carried out by putting points and grades in order to obtain information about the progress of students who have completed sections of the curriculum (General topics and a certain period of study (quarter, academic year, level of secondary education) [9].

Intensive globalization is also affecting the national economy, and international competition for economic development has increased. In addition to these economic evidence for the modernization of the education system in the modern twenty-first century there are other reasons: increase in the propensity to contacts, social changes, issues associated with weather change, intensive population growth worldwide, rising demand for scarce resources that are required by today's teenagers the skills necessary for a successful relationship with the modern world and needed to interact with the world of tomorrow. Therefore, it is important to provide them with modern programs and training methods, qualified specialists [8].

In the secondary education system, it is necessary to increase the level of education of secondary schools in Nazarbayev Intellectual schools. School graduates should know Kazakh, Russian and English. The result of their training should be the mastery of students 'skills of constructive thinking, independent search and deep analysis of information, - said the content of mass education is currently being updated in the country. According to the updated program, the world education system is focused on improving the competitiveness of students, so that they can find their place in society. As you know, until now in our country, students in secondary schools do not see the expected results, choose a specialty under the influence of various factors of influence, and ultimately can not be attracted to work in this specialty [7].

The curricula developed as part of the renewal of secondary education content are based on a spiral curriculum model, with repeated testing of knowledge and skills as students move from one class to another. In order to seemingly move the learning process, learning goals are combined in those parts and areas in which they are interfaced. For example, from simple to complex, from simple to complex, from simple to complex, from simple to complex, from simple to essay writing, a story can even write a novel, language competencies are developed.

The teaching method used by teachers is essential to ensure maximum standards of student learning. In this regard, during the development of the new programme will undoubtedly contribute to the effective teaching, pupils form 4 necessary skills (listening, pronunciation, subscription, read): «the role in the wall», «hot chair», «line reviews», «lane consciousness», «5 questions, 5 answers», «5 steps», «Technique of drama», «Area importance», «graphic organizeran individual diagram», «Double figure», «mountain events», «Hika map», «Stop frame»..

The method used by teachers has a significant impact on the effectiveness of teaching. Changing the curriculum before improving pedagogical methods reduces the possibilities and effectiveness of reform measures related to educational standards. According to the updated program each teacher achieved the following results:

- the structure of the updated curriculum;

- updated curriculum content and system;

- purpose and design of the curriculum and documentation related to its implementation; 
- to master the appropriate pedagogical approaches that contribute to the implementation of the educational program [5].

At the end of the refresher course, each teacher has achieved results that can use the content and consistency of the updated program, the appropriate pedagogical approaches that contribute to the implementation of the educational program. «Indeed, they say, the nature of man, the Ministry of education and science of the Republic of Macedonia man, flatterer. Meir premature premature observed», says Abay. In this regard, in accordance with the Law of the Republic of Kazakhstan «on religious activities and religious associations», as well as in order to implement the Law of the Republic of Kazakhstan «on religious activities and religious associations», «on religious activities and religious associations», the government of the Republic of Kazakhstan decides: 1 to approve the attached: 1) Regulations on the Committee on religious Affairs of the Ministry of culture and sports of the Republic of Kazakhstan; 2) Regulations on the Committee on religious Affairs of the Ministry

Mirzhakip Dulatov «the only support, only hope to learn. Within the framework of the program» business Road map-2020 «in Kostanay region, 3 billion tenge was allocated to support private entrepreneurship within the framework of the program» business Road map-2020 «in 2014 the bright star that begins kindness is reading. From something day is darkness, perspective is fog». It is no secret that the core of civilized development is education, science, education. In the presence of Akhmet Baitursynov teacher: "what will become a leader, that is, the knowledge of the teacher, if he is more shykpakshy education of children of the school. When in school need, above all, — education, pedagogy, metodikadan in rate, then, obviously, teacher», — spoke, that XXI century — age science. Purposeful education is a problem in which personal development is carried out [10].

And in accordance with this pan-European standard, new education is the only way to the comprehensive development of the individual! Creative abilities of teachers, innovative actions, qualification, physiological and mental qualities, correspond to pedagogical professional knowledge. In this pedagogical direction, mutual interaction between the teacher and the student, mutual development, achievement of a balanced, high level of development from cooperation is of great importance.

As a result, the essence of the updated educational program is the formation of functional literacy of students. The student must master the knowledge gained within the walls of the school, the real needs of life. For this purpose, the basis of this program is the concept of «connection with life». The teacher has a great responsibility. In order for students to be successful in the twenty-FIRST century in all spheres of life, instill the necessary skills, teachers must work restlessly. Within the framework of the updated curriculum, only those teachers who love their subject, their profession, and consider the life of a teacher powerful for a child can work. And we learn, and we learn, based on the teachings of the historical personality of the Indian people Mahatma Gandhi «If you want to notice changes in the future, do it in due time», improve our abilities and lead students into the future.

Our developing Republic cannot remain without the influence of these trends, the more confidently it declares itself at the international level. One of the urgent problems of our society is the formation of a competitive personality, ready not only to exist in changing social and economic conditions, but also to actively influence the modern truth. In this regard, teachers, fulfilling the orders of the society, should prepare a graduate within the walls of the school with a set of such qualities as creativity, social responsibility, possessing a developed intellect, a high level of professional literacy, stable motivation of cognitive activity [11].

The main goal of education in the modern world - training of a qualified specialist, competitive, competent, well-aware of his work in the labor market, oriented to the side, able to work effectively at the level of world standards, professionally grow, respond effectively to socio-political processes, quickly adapt to the changes, able to solve the industrial and innovative situation, to Express themselves in accordance with their needs and the needs of society, freely Express their thoughts, have a high knowledge of the national language, history, form domestic and world culture [12].

The transition to updating the content of education imposes new requirements to work within the competence approach to education, is to provide teachers with health technologies, formation of readiness to work in the conditions of individualization of the educational process. The renewal of the structure of education is the overcoming of the traditional reproductive style of education and the transition to a new developing, constructive model of education that provides cognitive activity and independence of thinking of students. 
We offer the upgrade program of education implies that learning must be active, must be created by the collaborative environment, should be the differentiation of learning, in the process of implementation must be implemented by interdisciplinary connections. In addition to the above, it is mandatory to use ICT, dialogue training, timely response to research methods and needs of students.

\title{
References
}

1 Н.Ә. Назарбаев «Төртінші өнеркәсіптік революция жағдайындағы дамудың жаңа мүмкіндіктері» жолдауы, № 633 Жарлық, 9 ақпан 2018 жыл [Электрондық ресурс]. — Қолжетімділік тәртібі: http://online.zakon.kz/.

2 Н.Ә. Назарбаев «Қазақстан-2030» стратегиясы - ел дамуының 2030 жылға дейінгі кезеңге арналған стратегиялық бағдарламасы» 19 қазан 2012 жыл [Электрондық ресурс]. — Қолжетімділік тәртібі: http://online.zakon.kz/.

3 Назарбаев Н.А. Взгляд в будущее: модернизация общественного сознания. 12 апреля 2017 года / Н.А.Назарбаев. [Электрондық ресурс]. — Қолжетімділік тәртібі: http://www.akorda.kz

4 Қазақстан Республикасының «Білімтуралы» заңы. 2007 жылғы 27 шілдедегі № 319 қаулысы [Электрондық ресурс]. — Қолжетімділік тәртібі: http://www.adilet.zan.kz

5 Қабылова А. Окушылардың іскерлік қарым-қатынас тілін дамыту / А. Қабылова // Қазақстан мектебі. — 2013. № 8. - Б. 3-7.

6 Ильенко Л.П. Современные модели обучения в общеобразовательных учреждениях: учеб. пос. / Л.П. Ильенко. — М.: АРКТИ, 2009. - $122 \mathrm{c}$.

7 Акулова О.В. Конструирование ситуационных задач для оценки компетентности учащихся: учеб.-метод. пос. для педагогов шк. / О.В. Акулова, С.А. Писарева, Е.В. Пискунова. - СПб.: Каро, 2008. — 90 с.

8 Дж. Петти. Современное обучение [пер. с англ. П. Кириллова]. — М.: Ломоносов, 2010. — 624 с.

9 Жансеркеева Г. Дамыта оқытудың тиімділігі / Г. Жансеркеева. — Алматы: Алматы кітап, 2010. — 52 б.

10 Смағұлова Қ.Ғ. Критериалды бағалауды нәтижеге бағыттау / Қ.Ғ. Смағұлова. — Астана: Сервис пресс, 2013. — № 1. $-125 \mathrm{c}$.

11 Қазиев Б. Кіріктірілген бағдарлама бойынша критериалды бағалау / Б. Қазиев // Қазақстан мектебі. — 2014. — № 6. - Б. 46-47.

12 Сарбасова Қ.А. Техникалық және кәсіптік білім берудің инновациялық жүйесін құрудың әдіснамалық негіздері / Қ.А. Сарбасова, Ж.Е. Алшынбаева // Вестн. Караганд. гос. ун-та. Сер. Педагогика. — 2015. — 3 (79). — С. $145-151$.

\author{
Н.Б. Михайлова, М.Т. Баймұқанова, Б.Қ. Пазылбек
}

\section{Жаңартылған оку бағдарламаларының ерекшеліктері және білім беру үрдісін жетілдіру}

\begin{abstract}
Мақалада Қазақстан Республикасының жаңартылған білім беру жүйесінің ерекшеліктері қарастырылған. Авторлар Қазақстан Республикасының білім саласына енген жаңартылған білім беру бағдарламасы - болашақ ұрпақтың сұранысын қанағаттандырады және заманауи талаптарға жауап береді деп санайды. Сонымен қатар, қазіргі замандағы білім беру жағдайында мұғалімнің инновациялық технологияларды игеруі және өз сабақтарында балаларды оқыту кезінде қолданудың объективті қажеттілігі туралы мәселе көрсетілген. Бұл тұлғаға бағытталған оқытуды, сонымен қатар оқушылардың шығармашылық әлеуетін ашуға жағдай жасауды талап етеді. Қазіргі замандағы білім берудің негізгі мақсаты - еңбек нарығында бәсекеге қабілетті, құзыретті, өз жұмысын жақсы білетін, жан-жағына бағыт-бағдармен қарайтын, әлемдік стандарт деңгейінде нәтижелі жұмысқа, кәсіби өсуге, әлеуметтік-саяси оңтайлы тез әрекет жасауға, болып жатқан өзгерістерге тез бейімделуге қабілетті білікті маман, индустриалды-инновациялық жағдайды шешуге лайық, өз қалауы мен қоғам талабына сай өзін көрсете білуге бейім, өз ойын еркін айта алатын, жоғары білімді, ұлттық тілді, тарихты жетік меңгерген, отандық және әлемдік мәдениетті бойына қалыптастырған, шығармашыл, оңтайлы кәсіби маман дайындау. Мақалада бағалау жүйесі де түбегейлі өзгеріске ұшырап, критериалды бағалау жүйесіне өтетіні баяндалған.
\end{abstract}

Кілm сөздер: жаңартылған білім беру жүйесі, критериалды бағалау, инновациялық білім беру, ақпараттық технологиялар. 


\title{
Н.Б. Михайлова, М.Т. Баймуканова, Б.К. Пазылбек \\ Особенности обновленных образовательных программ и совершенствование учебного процесса
}

\begin{abstract}
В статье рассмотрены особенности обновленной системы образования Республики Казахстан. Авторы считают, что внедренная в сферу образования Республики Казахстан обновленная образовательная программа удовлетворит потребности будущих поколений, ответит современным требованиям. Кроме того, вопрос об освоении учителем инновационных технологий в современных условиях образования и объективной необходимости их применения при обучении детей на своих уроках является актуальным, требующим использования личностно-ориентированного обучения, а также создания условий для раскрытия творческого потенциала учащихся. Основная цель образования в современном мире - подготовка квалифицированного специалиста, конкурентоспособного, компетентного, хорошо знающего свою работу на рынке труда, способного эффективно работать на уровне мировых стандартов, умеющего профессионально расти, эффективно реагировать на социально-политические процессы, быстро адаптироваться к происходящим изменениям, способного решать индустриальноинновационные ситуации, проявлять себя в соответствии со своими потребностями и потребностями общества, свободно выражать свои мысли, обладать высоким знанием, национальным языком, историей, формировать отечественную и мировую культуру. В статье подробно описано, что система оценивания подвергается кардинальным изменениям и находится на стадии перехода к системе критериального оценивания.
\end{abstract}

Ключевые слова: обновленная система образования, критериальная оценка, инновационное образование, информационные технологии.

\section{References}

1 N.A. Nazarbaev «Tortinshi onerkasiptik revoliutsiia zhahdaiyndahy damudyn zhana mumkindikteri» zholdauy, No. 633 Zharlyk, 9 akpan 2018 zhyl [Ukaz Prezidenta Respubliki Kazakhstan, dated 9 fevralia 2018 goda № 633]. Legal reference «Legislation». online.zakon.kz. Retrieved from http://online.zakon.kz/ [in Kazakh].

2 N.A. Nazarbaev «Kazakstan-2030» stratehiiasy - el damuynyn 2030 zhylha deiinhi kezenhe arnalhan stratehiialyk bahdarlamasy» 19 kazan 2012 zhyl [Poslanie Prezidenta Respubliki Kazakhstan N.Nazarbaeva narodu Kazakhstana, dated 19 oktiabria 2012 goda]. Legal reference «Legislation». online.zakon.kz. Retrieved from http://online.zakon.kz/ [in Kazakh].

3 Nazarbaev, N.A. Vzhliad v budushchee: modernizatsiia obshchestvennoho soznaniia [N.A. Nazarbayev «Look into the future: modernization of public consciousness» on April 12, 2017]. Legal reference «Legislation». akorda.kz. Retrieved from http://www.akorda.kz [in Russian].

4 Zakon RK «Ob obrazovanii» ot 27 iiyulia 2007 h. № 319-III [The Law of the Republic of Kazakhstan «On education», dated 27 July, 2007, No. 319-III]. Legal reference «Legislation». adilet.zan.kz. Retrieved from http://www.adilet.zan.kz [in Russian].

5 Kabylova, A. (2013). Razvitie yazyka delovoho obshcheniia studentov [Developing students ' business communication]. Shkola Kazakhstana - School of Kazakhstan, 8, 3-7 [in Kazakh].

6 Ilenko, L.P. (2009). Sovremennye modeli obucheniia v obshcheobrazovatelnykh uchrezhdeniiakh [Modern models of education in General education institutions]. Moscow: ARKTI [in Russian].

7 Akulova, O.V., Pisareva, S.A., \& Piskunova, E.V. (2008). Postroenie situatsionnykh zadanii dlia otsenki kompetentnosti studentov [Designing situational tasks for assessing students' competence]. Saint Petersburg: Karo [in Russian].

8 Petti, Dzh. (2010). Sovremennoe obuchenie [Modern education]. (P. Kirillova Trans.). Moscow: Lomonosov [in Russian].

9 Zhanserkeeva, G. (2010.) Effektivnost razvivaiushcheho obrazovaniia [The effectiveness of developmental education]Almaty: Almaty Kitap

10 Smagulova, K.Kh. (2013). Napravlenie kriteriev otsenki rezultata [The direction of criterion of estimation on the result]. Astana: Press-sluzhba .

11 Kaziev, B. (2014). Kriterialnaia otsenka po intehrirovannoi prohramme [Criteria-based evaluation of the integrated program]. Shkola Kazakhstana - School of Kazakhstan, 6, 46-47 [in Kazakh].

12 Sarbasova, I.O., \& Alshinbaeva, R.O. (2015.) Metodolohicheskie osnovy sozdaniia innovatsionnoi sistemy tekhnicheskoho i professionalnoho obrazovaniia 「Methodological foundations for creating an innovative system of technical and professional education]. Vestnik Karahandinskoho hosudarstvennoho universiteta. Seriia Pedahohika - Bulletin of the Karaganda University. Pedagogy Series, 3 (79), 145-151. 